ZHUMBEI Marianna - Candidate of Pedagogical Sciences, Associate Professor at the Department of Foreign Languages and Country Studies, Vasyl Stefanyk Precarpathian National University, 57, Shevchenko str., Ivano-Frankivsk, 76000, Ukraine

ORCID: https://orcid.org/0000-0002-8883-4135

DOI: https://doi.org/10.24919/2413-2039.12/44.7

To cite this article: Zhumbei M.a (2021) Dystantsiine navchannia yak alternatyva tradytsiinii osviti v chasy pandemii COVID-19. [Distance learning as the alternative to tradional education in times of COVID-19 pandemic]. Human Studies. Series of Pedagogy, 12 (44), 51-57, doi: https://doi.org/10.24919/2413-2039.12/44.7

\title{
DISTANCE LEARNING AS THE ALTERNATIVE TO TRADIONAL EDUCATION IN TIMES OF COVID-19 PANDEMIC
}

Summary. The article deals with the analysis of the world education situation caused by the COVID-19 pandemic. Distance learning has commonly been accepted as the sole and exclusive education solution at the time of emergent events resulting in closing of educational establishments in the world in 2020.

The distance learning ideas, introduction and organizational issues have found their partial coverage in certain scientific works, but the problem of crisis replacement of traditional education by distance learning remains insufficiently studied.

The distinct difference between the terms "distance learning" and "crisis distance education" is represented. It lies in sudden, unready and forceful implementation. To the differences we refer: suddenness, internationalism, popularity, expansion, imposition, etc.

The advantages, disadvantages and problems of the distance learning in higher education during the pandemic are studied.

Crisis can produce an environment where current changes in the system of education are more accessible than in regular times. The transition of the traditional education into the crisis distance education must be developmental.

Presently the scientific researchers state that the role of the educator must be reinterpreted. So, we come to the problem which remains a sharply debated question leading to a conflict between two prevailing teaching orientations: the teacher-centered approach against the student-centered approach.

Today, the teacher-centered approach is criticized for the reason of traditional standardized testing, failure to measure acquired knowledge and stimulate learning. Most online educators have found that a helpful way to think about teaching in a student-centered fashion will transform the distance learning into a producrive, effective and progressive process. Using distance learning technology, teachers should: inspire students, express creativity, provide individual support, encourage to learn, motivate students and engage them in the knowledge acquisition process.

The three forms of interaction for students in the online environment (student-content, student-student, student-instructor) are analyzed.

The situation of distance learning introduction in Ukraine is represented. Despite the fact that Ukrainian population is not characterized by a high level of digital literacy, there appear a number of other problems such as decreasing success rate of students, poor Internet quality and the lack or absence of devices for online learning.

The study emphasizes that successful functioning of distance learning in crisis period should be based on a student-centered approach to learning. The role of the teacher must be focused mainly on students and identifying of potential barriers of learning.

Key words: distance learning, crisis distance education, traditional education, student-centered approach.

ЖУМБЕЙ Маріанна - кандидат педагогічних наук, доцент кафедри іноземних мов і країнознавства, Прикарпатський національний університет імені Василя Стефаника, вул. Шевченка, 57, м. ІваноФранківськ, 76000, Україна

ORCID: https://orcid.org/0000-0002-8883-4135

DOI: https://doi.org/10.24919/2413-2039.12/44.7

Бібліографічний опис статті: Жумбей, М. (2021) Дистанційне навчання як альтернатива традиційній освіті в часи пандемії COVID-19. Людинознавчі студії. Серія «Педагогіка», 12 (44), 51-57, doi: https://doi.org/10.24919/2413-2039.12/44.7

(C) Zhumbei Marianna, 2021 


\section{ДИСТАНЦЙНЕ НАВЧАННЯ ЯК АЛЬТЕРНАТИВА ТРАДИЦІЙНІЙ ОСВІТІ В ЧАСИ ПАНДЕМІЇ COVID-19}

Анотація. Стаття присвячена аналізу світової ситуації в освіті, спричиненої пандемією COVID-19. Дистаниійне навчання прийняте як єдине та ексклюзивне освітнє рішення на час надзвичайних подій, щзо призвели до закриття навчальних закладів у світі в 2020 рочі.

В той час як ідеї, впровадження та організація прочесу дистаниійного навчання знайшли своє часткове висвітлення у певних наукових дослідженнях, проблема кризової заміни традииійної освіти дистаниійним навчанням залишається маловивченою.

Представлено чітке розмежування термінів «дистанційне навчання» та «кризова дистанційна освіта». Основна відмінність полягає в ї̈ раптовій, незапланованій та вимушеній реалізачії. До характерних рис кризової дистанційної освіти зараховують раптовість, інтернаціоналізм, поширення, популярність та нав'язування.

Вивчено переваги, недоліки та проблеми дистанщійного навчання у вищій освіті під час пандемії. Криза може створити середовище, в якому поточні зміни в системі освіти є більш доступними, ніж у звичайні часи. Перехід традиційної освіти в кризову дистаниійну освіту повинен мати розвивальний характер.

Нині науковці заявляють, щзо роль вчителя має бути переосмислена. Отже, в дослідженні ми підійшли до проблеми, яка залишається гостро обговорюваним питанням, щзо призводить до конфлікту між двома навчальними підходами: студенточентрованим та особистісно орієнтованим на вчителя.

Підхід, орієнтований на вчителя, піддається критиці через традиційне стандартизоване тестування, відсутність вимірювання набутих знань, стимулювання навчання тощо.

Більшість викладачів, щзо навчають студентів онлайн, заявляють, щуо навчання, яке базується на студенточентрованому підході, змінить дистаниійне навчання на продуктивний, ефективний та прогресивний процес. Таким чином, використовуючи технологію дистаниійного навчання, викладачі мають надихати студентів, виявляти творчі здібності, надавати індивідуальну підтримку, заохочувати до навчання, мотивувати та залучати студентів до проиесу набуття знань.

Проаналізовано три форми взаємодії студентів в Інтернет-середовищі: студент-контент, студент-студент, студент-викладач.

Досліджено ситуацію із впровадженням дистаниійного навчання в Україні. Незважаючи на той факт, щяо населення України не характеризується високим рівнем циифрової грамотності, виникає низка інших проблем, таких як зниження рівня успішності студентів, низька якість Інтернету та нестача чи відсутність пристроїв для онлайн-навчання.

У статті наголошується, щзо успішне функиіонування дистаниійного навчання в кризовий період має базуватися на студенточентованому підході до навчання, де роль викладача зосереджена головним чином на студентах та виявленні потенційних бар'єрів у навчанні.

Ключові слова: дистанційне навчання, кризова дистаниійна освіта, традиційна освіта, студентоцентрований підхід до навчання.

Introduction. The pandemic caused by COVID-19 has completely changed the process of education in the world. The traditional face-to-face education has been replaced by online education (e-learning) enabled by distance learning.

After the COVID-19 outbreak in December 2019, the World Health Organization classified COVID-19 as a global pandemic in March 2020 (WHO, 2020). Complete lockdowns or regulations to facilitate social distancing were introduced in many countries. Protocols to shut down buildings to prevent the infection included kindergartens, schools, universities. This situation forced all educational institutions to operate remotely and to put distance learning into practice.

The affected number of students equals around $90 \%$ of the world's enrolled students (UNESCO, 2020a). The interruption of education could have brought to the unpredicted consequences: fewer educational opportunities; confusion and stress for teachers; challenges creating, maintaining and improving distance learning; social isolation; negative impact on productivity, etc. (UNESCO, 2020g).

As a response to the global educational crisis the teaching and learning activities were immediately shifted to a complete world E-learning. E-learning is defined as learning performed by use of Information and Communication Technologies. The incorporation of technological resources 
and innovative education strategies has transformed the teaching and learning processes, methods, approaches (What is E-learning, 2020).

Analysis of recent publications. The ideas of introduction of distance learning into pedagogical practice are studied by O. Andreiev, V. Soldatkin, M. Moiseieva, V.Kuharenko, V, Rybalko, Y. Bohachkov, P. Fedoruk, etc. The leading foreign scientists J. Biggs, C. Feasley, J. Daniel, J. Foley, M. Galusha, C. Golden, D. Keegan, M. Moor, S. Riggs, M. Roblyer, C.Wedemeyer and others have done their research in the field of distance learning oranization.

Despite the fact that the distance learning ideas, introduction and organizational issues have found their partial coverage in certain scientific works, the problem of crisis replacement of traditional education by distance learning remains insufficiently studied.

The purpose of the article. The article is dedicated to the analysis of today's alternative of the traditional education - distance learning. The advantages, disadvantages and problems of the distance learning in higher education during the pandemic of COVID-19 are characterized.

Presentation of the main material. Distance education is represented as "an organisational and technological framework for providing instruction at a distance... When the teacher and student(s) are separated by geography, technology is used to bridge the gap" (Ham, 1995, p. 43). The generally accepted technology for bridging the gap is presently E-learning.

Feasley and Roblyer, Edwards \& Havriluk defined distance education using a variety of terms including "distance learning", "distance teaching", "open learning", and "remote learning", which according to them, all refer to learning situations that are alternatives to regular class meetings (Feasley, 1992, p. 334; Roblyer, Edwards \& Havriluk, 1992). According to Foley, "distance learning is both a location and a concept that allows teachers and students to communicate despite a separation of time and space" (Foley, 1998, p. 973).

Distance learning has been characterized by a number of positive features at all times:

- flexibility to learn at student's own place;

- variety of educational tasks, which enable learners to adapt their learning schedule according to their own learning style (self-paced study);

- flexibility for students to decide on their course of learning;

- saving time, as students can participate in the learning process from their homes;

- being profitable, as distance learning can assist both study and work.

To the disadvantages of distance learning we refer:

- sense of isolation;

- struggle with staying motivated;

- lack of face-to-face interaction;

- difficulty in getting feedback immediately;

- need for constant and reliable access to technology.

However, there appear a number of problems caused by distance learning among which we can introduce:

- inadequate preparedness of students;

- loss of motivation;

- feeling of isolation and uselessness;

- technical difficulties;

- poor course organization;

- lack of presentation skills and variation in quality of teaching;

- inexperience with this style of learning.

All the above mentioned issues lead to academic problems. Hence, we might primarily consider that traditional face-to-face education is rather effective and motivating for the learners.

The different opinion is expressed by a number of foreign researchers and Foley who stated that "research shows that distance education can be as effective as face-to-face instruction. Methods and technologies need to be appropriate to the instructional tasks. Learners need to be at the center of the process....Timely feedback is important to success" (Foley, 1998, p. 974).

Distance learning has become the sole and exclusive education solution at the time of emergent events resulting in closing of educational establishments in the world in 2020.

The new form of distance education (introduced into the system of education in the pandemic of 2020) is commonly named as crisis or pandemic distance education and differs from conventional distance education by being suddenly, unreadily and forcefully implemented. 
Education in time of crisis is a process relating to the formation of the population being affected by natural disasters and/or armed conflict (Sinclair, 2001, p. 20). Crisis distance education (CDE) is unique in its philosophies and procedures, being fundamentally different from traditional distance education in several ways. The differences are its:

- suddenness. CDE has been employed in schools out of an unforeseen need, with neither prior regulations nor preparation. It has been 'pushed' into society without the necessary skills and knowledge;

- internationalisation. CDE has been applied as total intervention across the world. It has been set as a generic, universal resolution, blind and deaf to local requirements, forming a global reality and turning instruction into a worldwide spectacle;

- popularity. It has become a common interest across societies, dominating the public sphere. Google Trends demonstrates that the search frequency for the phrase 'distance education' has multiplied dozens of times in the aftermath of the coronavirus crisis;

- expansion. In this time, distance education has become an instructional means for all different age cohorts, from kindergarten to doctoral levels;

- imposition. It has taken place with neither voting nor any form of democratic decision-making. It has been enforced as a primary device for the completion of individuals' educational journeys.

- medical emergencies. Whereas distance education is often touted for reasons such as geographical isolation, disability and wars, it is now being used as a tool for dealing with a medical tragedy (Lily, Ismail \& Abunasser, 2020).

By definition, distance education further places emphasis on interactions between different parties and through different channels to let learners be more engaged in the learning process (Moore, 1989). In this sense, online distance education and CDL are not the same things. What is currently being done, CDL should be considered a temporary solution to an immediate problem (Golden, 2020). Crisis can produce an environment where current changes in the system of education can be more accessible than in regular times. The transition of the traditional education into the CDL must be developmental.

Thereby, the scientific researchers state that the role of the educator must be reinterpreted in the CDL. This idea brings us to the problem which remains a sharply debated question leading to a conflict between two prevailing teaching orientations: the teacher-centered approach versus the student-centered approach.

According to the first approach, the teacher is the main source of knowledge and the learner follows the teacher's instructions to learn the material. On the other hand, according to the second approach, education should be centered on the needs and abilities of the learner. The teacher's role is to facilitate the learning process rather than to provide the knowledge.

Different systems of education in the world supported these two approaches at different times. For example, the United States, Canada and the European Union spend significant resources to promote a student-centered approach at all levels of education. Due to the student-centered approach such derivative approaches as cooperative learning, student-centered instruction and hands-on learning have been developed and introduced into the process of education.

The former Soviet Union countries including Ukraine, inherited from the Soviet Union a pedagogy that focused predominately on the teacher-centered approach.

The idea of the teacher-centered approach lies in the usage of traditional methods of teaching (e.g. formal lectures, seminars and examinations). The teacher is in the centre of the educational process and provides structured material at the lectures listened by the students. Then, during seminars, the teacher checks if the students have understood the material. Finally, the received knowledge is tested at the examinations in the end of the term and before the university graduation.

Unfortunately, in most situations such conditions may promote a "surface" rather than "deep" level of understanding and orient students towards performing only at the minimal level required to obtain a good grade in the course (Biggs, 1999).

However, the recent openness to Western values, promoting a mainly student-centered approach, is now changing the traditional Soviet-based educational system and precisely the Ukrainian one.

Today, the teacher-centered approach is criticized for the reason of traditional standardized testing, placing students in a passive, reactive role, instead of engaging their capacities to come up with ideas, solve problems or structure various tasks which greatly fail to measure acquired knowledge and stimulate learning (Darling-Hammond, 1994, p. 7). 
Using distance learning technology, teachers should:

- do their best to inspire students;

- give creative answers;

- express critical thinking;

- provide contextual feedback;

- assess;

- provide individual support;

- encourage to learn;

- motivate students;

- be involved in the teaching process;

- engage in the knowledge acquisition process.

Thus, by changing the role of the teacher in the process of learning and teaching the quality of education in the crisis period has been transformed completely, developed progressively and, undoubtedly, improved. The teacher is no longer a knowledgeable resource of information delivery but a guide, an inspirer, a facilitator of learning and an influencer.

The problem of student-centered approach is widely researched by such Ukrainian and foreign scientists as: I. Babyn, V. Zaharchenko, V. Kremen', T. Kuprii, O. Martynchuk, A. Stavytskyi, E. Shchukina, G. Gibbs, Z. Boyovic, J. Keengwe, O. Marjanovic, T. Lapidot, R. Leow, N. Ragonis, D. Taylor, etc.

Most online educators have found that a helpful way to think about teaching in a student-centered fashion is to focus on creating three forms of interaction for students in the online environment:

1. Student-content interaction, where instructors provide active learning experiences for students (meaningful learning activity plus reflection: write a summary on reading; diagram a process; complete a poll to check comprehension; illustrate ideas on the whiteboard; prepare multimedia presentations; create collages and blog posts related to course content);

2. Student-student interaction, where instructors structure the learning community and make it clear to students how they should interact with others in the class (participate in a role-play or debate activity; group projects; group presentations; individual projects; create a resource guide for future students; design a board game based on course content);

3. Student-instructor interaction, where instructors create a framework for how they will interact with students during the learning experience (engage with students about the course content via discussion forums; record and post a short video to introduce a major assignment and then hold a "question and answer" session; provide detailed feedback on assignments (written and/or recorded); use voice-over screen recordings; use tools to provide demonstrations; discuss diagrams/graphs, slides, and illustrations; hold writing conferences to discuss draft assignments; hold open or by-appointment office hours by web conference, phone, or text message (Riggs, 2020).

Fortunately, distance learning has become one of the most progressive educational methods of the last decade. According to recent findings, during 2014 about 5.8 million students were registered in distance education and one half of which were learning in a fully online environment (Allen \& Seaman, 2017).

As we have already mentioned above, Ukraine is one of the post-soviet countries located in Eastern Europe striving to be integrated in economic and political structures of the EU. The current population of the country is 42 million. Despite the low incomes of many Ukrainians, modern technological devices are widespread among the population. The State Statistics Service of Ukraine reported that the number of Internet subscribers in the country was $26 \mathrm{mln}$ in 2019. However, the Ukrainian population is not characterized by a high level of digital literacy yet. According to the Digital Transformation Ministry of Ukraine, almost 38\% of Ukrainian people aged from 18 to 70 have poor skills in computer literacy and $15.1 \%$ of the citizens have no computer skills (The Cabinet of Ministers of Ukraine, 2020). The survey conducted by the Digital Transformation Ministry of Ukraine informed that 27.5\% Ukrainian families have a tablet, $30.6 \%$ have one smart phone, $26.4 \%$ have two smart phones, $16.5 \%$ have three smart phones and $10.8 \%$ have four and more smart phones. As for laptops, $42.7 \%$ Ukrainian families have a laptop and $45.6 \%$ have a desktop computer (The State Statistics Service of Ukraine, 2019). The data from the ministry did not indicate if families have multiple devices, however, the data shows that technological devices are widespread.

Presently, about half of Ukrainians do not approve of the implementation of distance learning in the wake of the pandemic; $32 \%$ support this initiative. The most pressing problems that Ukrainians 
are facing due to distance learning are the decreasing success rate of students $(22 \%)$ and technical issues: poor Internet quality (21\%) and the lack or absence of devices for online learning (19\%) (Education and the Pandemic, 2020). Nonetheless, with the development of learners' digital skills the process of adaptation to the distance education will occur in rather a favourable atmosphere.

Thus, the common introduction of distance learning into the system of education has turned out to be the sole decision in present world situation and the alternative to the tradional education. We come to the conclusion that for the new education methods to be progressive and productive, teachers need to design new learning activities and help students acquire knowledge by adopting and integrating distance learning tools and technologies properly. We emphasize that successful functioning of distance learning in crisis should be based on a student-centered approach to learning. The role of the teachers must be focused mainly on students, identifying of potential barriers of learning, such as motivation, learning feedback, communication with instructors, student support, sense of isolation and training.

Finally, what the students learn in these times might be of secondary importance because they will remember not the delivery of educational material and the content itself but their feelings and emotional state of mind during the pandemic. So, in course of time the distance learning has to become rather flexible, better prepared, motivating and well-organized to deliver both educational content and students' psychological preparedness. Our further research is based on the study of students' satisfaction with online learning and the possible improvements of distance education in Ukraine.

\section{BIBLIOGRAPHY}

1. Allen, I.E., \& Seaman, J. Digital compass learning: Distance education enrollment report 2017. Boston: Babson survey research group. URL: https://educationaltechnologyjournal.springeropen.com/articles/10.1186/ s41239-020-00194-2 (last access 14.02.2021).

2. Biggs, J. Teaching for Quality Learning at University. St. Edmundsbury Press, Suffolk, 1999. 357 p.

3. Communications Department of the Secretariat of the CMU. Oleksiy Honcharuk: National Digital Literacy Platform "Diia: Digital Education". URL: https://www.kmu.gov.ua/en/news/oleksij-goncharuk-nacionalna-osvitnyaplatforma-z-cifrovoyi-gramotnosti-diya-cifrova-osvita-startuye-vzhe-21-sichnya (last access 10.03.2021).

4. Darling-Hammond, L. Performance based-assessment and educational equity. Harvard Educational Review, 1994. No. 64, (1). Pp. 5-30.

5. Education and the Pandemic: the attitudes of Ukrainians towards distance learning and External Independent Testing in 2020. URL: https://dif.org.ua/en/article/education-and-the-pandemic-the-attitudes-of-ukrainianstowards-distance-learning-and-external-independent-testing (last access 15.03.2021).

6. Feasley, C.E. Distance education. Encyclopedia of educational research /in M. C. Alkin ed. New York: Macmillan, 1992. Pp. 334-342.

7. Foley, J.K. Distance education for American universities and the world. American Journal of Agricultural Economics, 1998. No. 80, (5). Pp. 973-979.

8. Golden, C. Remote teaching: The glass half-full. EDUCAUSE Review. URL: https://er.educause.edu/ blogs/2020/3/remote-teaching-the-glass-half-full (last access 01.04.2021).

9. Ham, R. Distance education: Teaching tools for the 21 century. The Technology Teacher, 1995. No. 54, (6). Pp. 43-45.

10.Lily, A.L., Ismail, A.F., Abunasser, F.M. Distance education as a response to pandemics: Coronavirus and Arab culture. 2020. URL: https://www.ncbi.nlm.nih.gov/pmc/articles/PMC7387275/ (last access 10.04.2021).

11. Moore, M.G. Editorial: Three types of interaction. American Journal of Distance Education, 1989. No. 3, (2). Pp. 1-7. URL: https://doi.org/10.1080/08923648909526659. (last access 03.03.2021).

12.Riggs, S. Student-centered remote teaching: Lessons learned from online education. Educause, 2020. URL: https://er.educause.edu/blogs/2020/4/student-centered-remote-learning. (last access 03.03.2021).

13. Roblyer, M.D., Edwards, J., Havriluk, M.A. Integrating educational technology into teaching. Upper Saddle River, NJ: Merrill, 1997.

14. Sinclair, M. Education in emergencies. Learning for a future: Refugee education in developing countries. UNHCR, Geneva, Switzerland, 2001. Pp. 1-84.

15. The Cabinet of Ministers of Ukraine. Presentation of the First Digital Literacy Survey in Ukraine (2019). URL: http //www.youtube.com/watch?v=t3ghLyjzqLM\&feature=youtu.be (last access 03.03.2021).

16. The State Statistics Service of Ukraine. Communication Subscribers as of January 1, 2019. URL: http://www. ukrstat.gov.ua/operativ/operativ2019/zv/az/az_e/az0119_e.htm (last access 04.03.2021).

17.UNESCO (2020a). COVID-19 education. URL: https://en.unesco.org/covid19/educationresponse/ globalcoalition (last access 03.02.2021).

18. UNESCO (2020g). Adverse consequences of school. URL: https://en.unesco.org/covid19/educationresponse/ consequences (last access 02.02.2021). 
19. What is E-learning. URL: https://www.igi-global.com/dictionary/administrators-assessments-online-courses-student/8785). (last access 10.02.2021).

20.WHO. Coronavirus disease (COVID-19) Pandemic. World Health Organization: web-site. URL: https:// www.who.int/emergencies/diseases/novel-coronavirus-2019. (last access 07.02.2021).

\section{REFERENCES}

1. Allen, I.E., \& Seaman, J. (2017). Digital compass learning: Distance education enrollment report 2017. Boston: Babson survey research group. URL: https://educationaltechnologyjournal.springeropen.com/articles/10.1186/ s41239-020-00194-2 (2021, February, 14).

2. Biggs, J. (1999). Teaching for Quality Learning at University. St. Edmundsbury Press, Suffolk. 357. [in English].

3. Communications Department of the Secretariat of the CMU. Oleksiy Honcharuk: National Digital Literacy Platform "Diia: Digital Education". URL: https://www.kmu.gov.ua/en/news/oleksij-goncharuk-nacionalna-osvitnyaplatforma-z-cifrovoyi-gramotnosti-diya-cifrova-osvita-startuye-vzhe-21-sichnya [in Ukrainian] (2021, March, 10).

4. Darling-Hammond, L. (1994). Performance based-assessment and educational equity. Harvard Educational Review, no. 64 (1), 5-30. [in English].

5. Education and the Pandemic: the attitudes of Ukrainians towards distance learning and External Independent Testing. URL: https://dif.org.ua/en/article/education-and-the-pandemic-the-attitudes-of-ukrainians-towardsdistance-learning-and-external-independent-testing [in English] (2021, March, 15).

6. Feasley, C.E. (1992). Distance education. In M. C. Alkin (Ed.), Encyclopedia of educational research, 334-342. New York : Macmillan [in English].

7. Foley, J.K. (1998). Distance education for American universities and the world. American Journal of Agricultural Economics, no. 80 (5), 973-979 [in English].

8. Golden, C. (2020). Remote teaching: The glass half-full. EDUCAUSE Review. URL: https://er.educause.edu/ blogs/2020/3/remote-teaching-the-glass-half-full [in English] (2021, April, 1).

9. Ham, R. (1995). Distance education: Teaching tools for the 21 century. The Technology Teacher, no. 54 (6), 43-45 [in English].

10. Lily, A.L., Ismail, A.F., Abunasser, F.M. (2020). Distance education as a response to pandemics: Coronavirus and Arab culture. URL: https://www.ncbi.nlm.nih.gov/pmc/articles/PMC7387275/ [in English] (2021, April, 10).

11. Moore, M. G. (1989). Editorial: Three types of interaction. American Journal of Distance Education, no. 3 (2), 1-7. URL: https://doi.org/10.1080/08923648909526659 [in English] (2021, March, 3).

12. Riggs, S. (2020). Student-centered remote teaching: Lessons learned from online education. EDUCAUSE Review. URL: https://er.educause.edu/blogs/2020/4/student-centered-remote-learning [in English] (2021, March, 3).

13. Roblyer, M.D., Edwards, J., Havriluk, M.A. (1997). Integrating educational technology into teaching. Upper Saddle River, NJ: Merrill [in English].

14. Sinclair, M. (2001). Education in emergencies. Learning for a future: Refugee education in developing countries, 1-84. UNHCR, Geneva, Switzerland. [in English].

15. The Cabinet of Ministers of Ukraine 2019. Presentation of the First Digital Literacy Survey in Ukraine. URL: https://www.youtube.com/watch?v=t3ghLyjzqLM\&feature=youtu.be [in Ukrainian] (2021, March, 3).

16. The State Statistics Service of Ukraine 2019. Communication Subscribers as of January 1. URL: http:// www.ukrstat.gov.ua/operativ/operativ2019/zv/az/az_e/az0119_e.htm. [in Ukrainian] (2021, March, 4).

17.UNESCO (2020a). COVID-19 education. URL: https://en.unesco.org/covid19/educationresponse/ globalcoalition [in English] (2021, February, 3).

18. UNESCO (2020g). Adverse consequences of school. URL: https://en.unesco.org/covid19/educationresponse/ consequences [in English] (2021, February, 3).

19. What is E-learning. URL: https://www.igi-global.com/dictionary/administrators-assessments-online-coursesstudent/8785). [in English] (2021, February, 10).

20. WHO 2020. Coronavirus disease (COVID-19) Pandemic. World health Organization. URL: https:// www.who.int/emergencies/diseases /novel-coronavirus-2019. [in English] (2021, February, 7). 